This article has been scanned by iThenticat No plagiarism detected

Volume 3, Issue 2, April 2021

p. $55-73$

\title{
APPLICATION OF INTEGRATION COMPREHENSIVE STUDENTS WITH SPECIAL NEEDS BETWEEN REALITY AND EXPECTATIONS FROM THE POINT OF VIEW OF TEACHERS IN SCHOOL'S PRIMARY IN BRIGADE NORTH IN GREEN LINE
}

\author{
http://dx.doi.org/10.47832/2757-5403.2-3.6
}

\section{Naaila Jeries HADDAD 1}

\begin{abstract}
:
The study aimed to identify the application of inclusion, to apply the comprehensive integration of students with special needs between reality and expectations from the viewpoint of teachers in primary schools in the Northern District within the Green Line. To achieve the aim of the study, the descriptive and analytical approach was used, through the development of the study tool, and verification of its validity and reliability. The study sample included (450) teachers chosen randomly. The results of the study showed that the degree of application of comprehensive integration of students with special needs between reality and expectations The teachers 'view of primary schools in the northern district within the green line came with a degree of (medium), and the results showed that there were no statistically significant differences in the areas of comprehensive integration of students with special needs between the reality and the expectations from the teachers' point of view in the primary schools in the northern district within the line. Green is attributed to the gender variable, academic qualification, and years of experience variable, while the results showed differences according to the job title variable, and the existence of differences according to the limitations of the merged student.
\end{abstract}

Key words: Comprehensive Inclusion, People With Special Needs, Reality and Aspirations, Primary Schools, The Green Line.

\footnotetext{
${ }^{1}$ Dr., Rimar Academy, naailahaddad@gmail.com, https://orcid.org/0000-0002-3092-1914
}

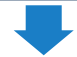

Published: 01/04/2021 


\section{Introduction}

Attention to people with special needs has become an important criterion for the progress of nations, especially in light of the successive changes that contemporary societies are going through and the changes that characterize life in terms of concepts of life and the direct effects of education, which has led to the need to pay more attention to them and develop their educational systems to keep pace with these changes.

All children have the right to education, regardless of their individual nature or characteristics. This right is educationally justified, which is the need for all children to have the right to compulsory education, in addition to that the school should prepare all educational and social programs according to the individual differences of each student, because the education of all children is the base of society and the most just and helps people live in peace. In all respects as well as from an economic point of view, teaching all students in one class is less expensive than establishing schools with multiple fields and specializations (UNESCO, 1994, p. 8).

The universal declarations and legislative texts issued by the countries of the world represent the interest of the child who wishes to obtain special needs from his rights in life, especially his right to education, and the Ministry of Education within the Green Line follows this approach, through the Special Education Law, which was enacted in the Knesset in 1998 which It aims to enhance and develop the skills of children with special needs in order to facilitate their integration into society and the work circle, and the law stipulates the following:

According to the Special Education Law; "Every child (or young person) between the age of 3 and 21 years old and has special needs, that is, he suffers from a severe disability as it is physical, mental, psychological, behavioral-emotional, cognitive or linguistic, or comprehensive developmental disabilities, and because of this, his ability to adapt his behavior is limited. Thus, he is entitled to free special education for the child in his area of residence or anywhere else. " (Ministry of Education, 2018).

Taking care of people with special needs is one of the necessities of life, and through the school as an educational institution, one of the first steps of social equality among members of society can be achieved, which begins with providing equal educational opportunities for every student. As a human being with rights and duties, he provides his services to all members of society who are obligated to prepare them for jobs that are compatible with their preferences and abilities, and which the society needs for the sake of comprehensive development (Al-Shuhaibi, 2009, p. 264)

Qualifying students with special needs and educating and training them to adapt to their society is not sufficient in the field of modern special education. If the school and the community do not cooperate in helping him to overcome the educational difficulties he is facing as appropriate; And adapting the natural environment to meet his needs and requirements so that there is continuous interaction between the two sides. So, the natural environment received attention, and the idea of a barrier-free environment was born, which is based on the fact that there are man-made obstacles in the environment, or they may exist and must be modified in both buildings, facilities, housing, transportation and other private and public devices, to become suitable for these groups to interact. Freely with the community and the environment surrounding them, and to facilitate their integration into society after their education, qualification, training and development through integrated and educational media programs; To remove the impurities associated with some practices towards them, and to facilitate their participation in work and normal life (Ibrahim, 2005). It also defined "accessibility" according to the Law on Equal Rights for Persons with Disabilities 1998: "Being able to reach every place, move around and know it, use it and enjoy the services it provides, get the information provided by the place or service, use the devices available in the place and participate in programs and events that it is provided by space, and all this is done with equality, respect, independence and safety" (Ministry of Education, 2018). 
Studies indicate a multiplicity of forms and methods of caring for students with special needs, and among these methods that have spread widely in many countries of the world is the method of inclusion (Saeed, 2003).

In the Ministry of Education, we find that it is making great efforts to raise awareness of the importance of integrating students with special needs into regular education frameworks, and from this vision many programs have been built on the subject of integrating this category into regular education. This is because comprehensive inclusion policies indicate a radical shift from the principle of emphasizing assistance to pupils with special needs to adopting a completely different learning and learning environment where all students, including those with special needs, are treated equally and in the same way. The goal of comprehensive inclusion policies is to develop an educational system in which students with special needs are treated on an equal footing with ordinary students within neighborhood schools, in regular classes and in school activities. As a result, this requires changes in classroom management and a shift in public education policy (Al-Otaibi, 2002, p. 8).

Like all other types of education, education for people with special needs has its own problems that it shares with others in addition to its problems that are unique to them, which come to the fore in its peculiarity: the inflexibility of regular education, insufficient administrative support, and the lack of support services for special education, And attention to quantity at the expense of quality, and the weakness of the relationship between educational practices and the results of scientific research, in addition to the absence of teamwork, and the great shortage of trained technical personnel, organization tools, curricula, and sources of scientific interest (Al-Khatib, 2008).

\section{Previous studies:}

In this part, previous studies related to the subject of this study are presented and are dealt with chronologically from the most recent to the oldest.

Al-Muzairi and Hanafi (2019) conducted a study aimed at identifying teachers 'expectations towards the implementation of comprehensive education for deaf and hard of hearing students in public education schools in Riyadh, and to identify the differences between the averages of teachers' expectations response towards the implementation of comprehensive education for the deaf and hard of hearing in public education schools in Riyadh according to a variable (Gender, academic qualification, experience, specialization), and the researcher used that in this study the descriptive and analytical method, the study relied on a questionnaire, and the study sample included all teachers in Riyadh, and their number reached (252) teachers, and the results of the study came as follows -1 Teachers 'expectations towards the implementation of comprehensive education for deaf and hard of hearing students in general were positive. - 2 The results showed that there were no statistically significant differences according to the "gender" variable. The results also showed that there are statistically significant differences according to the difference in the scientific qualification variable in favor of the learners (Bachelor's). The results also showed that there are statistically significant differences about the teachers 'expectations according to the experience variable in favor of those with more than 10 years of experience, and the results also showed the presence of significant differences. A statistic according to the specialization variable for public education teachers.

Nawasrah and Mansi (2018) conducted a study aimed at uncovering teachers 'attitudes toward integrating students with special needs with ordinary students in the primary stage in Ajloun Governorate schools in Jordan. It also aimed to determine the extent to which teachers 'attitudes differ according to the different variables of gender, academic qualifications, years of experience, age, and educational courses. The researchers used a questionnaire, and the sample consisted of (141) male and female teachers, the results showed that the trends were negative, and there were no statistically significant differences in teachers' attitudes. Depending on the gender variable and academic qualification, it was also found that there are statistically significant differences in teachers 'attitudes according to the age variable in favor of (age from 22-30) and the experience variable in favor of (experience from 1-5 years) and the training course variable in favor of those who did not receive any training. The necessity of preparing teachers who teach in basic schools and equipping schools with rooms and educational means necessary for integration, educating students and helping them to accept those with needs. 
Al- Sweiti (2016) also conducted a study aimed at identifying the attitudes and opinions of teachers and administrators in public education towards the inclusion of extraordinary children in regular primary schools in the Hebron area, where the study sample consisted of (110) teachers and administrators, and the study used a questionnaire. The tool included (26) paragraphs distributed on three dimensions, and the study found that the most acceptable disabilities in public schools are mild and simple disabilities, and that teachers 'attitudes towards inclusion in general were positive, and that there were no differences between teachers and administrators towards integrating the disabled with ordinary students, as well as The results indicated that there were no differences attributed to the teacher or administrative sex with regard to merging, and the results also indicated that there were no differences attributed to years of experience, as it was found that the more years of experience, the greater the acceptance process.

Al-Sharaa and Melhem (2014) conducted a study aimed at identifying the attitudes of lower elementary school teachers in Mafraq governorate towards students with learning disabilities who were integrated into regular schools. The sample of the study consisted of (49) teachers from the lower primary stage teachers (second and third grades), and their number was (21) teachers, and (28) teachers. To achieve the aim of the study, the two researchers used a questionnaire that was composed in its final form (32) paragraphs. The results showed the following: The primary school teachers are high trends, where the average arithmetic on the scale as a whole (3.68). There are no statistically significant differences for teachers' attitudes due to the gender variable, the educational qualification variable, or the experience variable.

Al-Najjar and Jundi (2014) conducted study aimed to identify at the attitudes of primary school teachers and teachers in the education schools in the south of Hebron, towards the integration of disabled people in their schools from their point of view by gender variable and academic qualification, marital status, years of experience, and to achieve these goals has been applied tool the study (questionnaire) consisting of a (200 samples) teachers, selected random sample stratified way, was used descriptive and analytical approach .The results of the study showed that the attitudes of primary school teachers in education schools in southern Hebron towards integrating the disabled in their schools were moderate in general. In addition, there were no statistically significant differences in the attitudes of primary school teachers in education schools south of Hebron according to the gender variable, academic qualification, marital status and years of experience .

Other study by Gemma, (2009) respond to the Salamanca UNESCO statement on the merger. In this study, the trends of (500) primary education teachers selected from three regions in Ghana out of ten regarding the integration of students with special educational needs in public education schools in Ghana were analyzed. Teachers' characteristics were studied, such as age, academic qualification, gender, level of teaching experience, level of knowledge of students with special educational needs, type, nature and degree of their disability. The results showed that teachers 'attitudes in Ghana were positive towards the inclusion of children with special educational needs. The results of the study also showed that there were statistically significant differences in age and years of experience in favor of the age group (30-40 years) and experience (more than 10 years). The study did not show any differences between teachers 'attitudes due to academic qualification and gender.

Likewise, the study done by Pantila (2008) aimed to know the attitudes and attitudes of Greek and Cypriot primary education teachers towards teaching children with special educational needs in regular schools. The tool used was based on the "theory of planned behavior." The study sample included 179 male and female teachers, 87 from Greece (34 male and 52 female teachers) and 92 from Cyprus (15 male and 70 female teachers). Descriptive statistics indicated that school teachers have positive attitudes towards educating students with special educational needs. The results of the study showed that teachers 'attitudes were different and were attributed to variables of experience, number of training courses, and educational level. In conclusion, experience, strength of attitude, self- 
identity, knowledge, and information, as well as higher education, on the subject of special education, have a positive effect on the attitudes and intentions of people who want to educate pupils with special needs. The study showed that the variables in which the difference lies between teachers, with teachers in Cyprus having the highest records, in addition to that, in addition to that, in addition to that, all of them have a lower university education in special education.

Varnado (2002), conducted a study aimed at knowing the attitudes of teachers and managers regarding the integration of students with special needs towards comprehensive inclusion within the education authority in Pennsylvania, in the United States of America. The sample included (20) teachers and directors of special and general education, and the results showed positive trends for the idea of integrating people with special needs in regular schools, and the results showed a greater preference for this idea among teachers with special needs than regular education teachers.

Hopps (2002) in his study aimed at comparing public education teachers with special education teachers in terms of their level of knowledge of special education laws and inclusion policies. This study relied on more than (450) teachers of public education and special education in Florida, Georgia and South Carolina, where the researcher used the mixed method in designing the research and followed the causal comparison approach in applying the study, and the researcher concluded that special education teachers by virtue of their specialization possess legal knowledge More than general education teachers.

\section{Study problem:}

Education is now in all developed and developing societies a right for every human being regardless of his abilities and talents, so students with special needs must have a place in the school. Hence, schools must work to introduce appropriate modifications and changes in their curricula, methods and buildings in proportion to the needs of this group of students. Attention must also be paid to school cadres to accept the idea of inclusion, which has positive effects on the educational process on the one hand, and on the mental health of students on the other hand. The attitudes of school teachers are among the most supportive factors for the success of educational inclusion. Given the amendment of the Special Education Law in the Ministry of Education; And basic amendments in Law 2003.

\section{Research objectives:}

Aim of this study to identify on the reality of comprehensive integration of students with special needs in - green line.

\section{Significance of research:}

The importance of research in theory lies in providing perceptions, theoretical frameworks and studies on this topic. The importance of applied research also lies in revealing the reality of the situation for the comprehensive integration of students with special needs and what should be (hopefully) from the teachers' point of view.

\section{Search terms:}

Students with special needs: The term (students with special needs) means an individual who needs, throughout his life or in a period of his life, special treatment in order to grow, learn, train, or conform to the requirements of his daily, family, career or professional life, and thus he can participate in the development processes. Socio-economic as much as he can and as much as a citizen (Al-Zuhairi, 2003). They are also individuals who differ from the general members of society, because they have special needs that are unique to them and not others, and those needs are the programs, services, methods, devices, tools, or modifications that all or some of their living conditions require, and their nature, size and duration determine the characteristics that characterize them. Each of them (Boutros, 2010).

The researcher believes that people with special needs are individuals who suffer from clear deficiencies in one or more of the following: physical deficiencies, psychological deficiencies, mental retardation, behavioral-emotional deficiencies, sensory deficiencies, general developmental deficiencies, and these deficiencies limit their ability to integrate into the 
school framework. Ordinary. This calls for the necessity of providing educational and educational programs and services that are commensurate with the type of deficiencies they have, so that they can adapt to society.

Comprehensive inclusion: Inclusive education aims to teach students with special needs alongside their peers all the time in regular classrooms in general education schools, allowing positive interaction and effective communication between the two parties in all activities, by providing all the necessary methods that ensure Universal access to adequate and appropriate education (Ali, 2013).

The researcher believes that the comprehensive integration is the integration of all students with special needs with a physical, psychological or mental disability, fixed or temporary, due to which the person is largely limited to his performance in one or more areas of his basic life in the regular class.

Integration within the Green Line: Much remains to be done in order for him to speak of comprehensive integration. Interest in people with special needs began in 1988, and the law refers to comprehensive integration, although this is not the case, but what exists is integration, not comprehensive integration. "There are many difficulties, such as the existence of programs, laws, and institutions, which operate on inequality but unintentionally. Consequently, there must be a change in attitudes and attitudes regarding the educational administration and teachers" (UNESCO, 1994, 2008).

According to Ministry of Education 2015 data, 220,000 students with disabilities have studied in the education system. $60 \%$ of them are integrated in general education $(131,000$ children), about $20 \%$ in educational classes in a general educational framework, $20 \%$ are enrolled in educational frameworks, and $40 \%$ of persons with disabilities have completed their education up to the primary stage at most, compared to $26 \%$ among the general population Only $52 \%$ of them have a high school diploma, compared to $73 \%$ among the general population. The low educational level of persons with disabilities is a common factor for men and women alike to report, and the picture becomes more and more severe, when the report addresses the Arabs at home, who constitute $18 \%$ of the total population (more than a million and a half people). The report stated that $73 \%$ of people with disabilities are unemployed, compared to $40 \%$ of the unemployment rate among the non-disabled (Equal Rights of Persons with Disabilities, 2017, p. 46).

The Private Education Law: In July 1988, the Knesset ratified the Special Education Law, and it began to be implemented in 1996. The integration program that was implemented following the application of the law addressed students from 5 years old to middle school (comprehensive). In 2003, Chapter Four was added to the Special Education Law: Integration of pupils with special needs into regular schools. There was also another amendment to the Special Education Law, and the amendment (No. 11) entered into force on January 1 of the year 2019. The amendment was gradually applied to students starting from the 2020 academic year (Ministry of Education, 2020).

\section{Research limits:}

- Human limits: The study was limited to a sample of teachers in primary schools in the Northern District, within the Green Line.

- The limits of time: conducted the study during the Chapter II of the general academic 2021-2020.

- Spatial boundaries: The Northern District within the Green Line.

\section{Method and procedures}

Ensure that this section describes the methodology of the study and study population, and sample section, and statistical analysis which were used to gain access to the results of the study.

Study methodology: 
To achieve the objectives of the study and to answer all questions have been using the method of descriptive analytical, which aims to describe the phenomenon, interpret, analyze, evaluate and develop and to achieve the goals of the study, it was from through the distribution of questionnaires and collected and analyzed statistical methods appropriate.

\section{Study population:}

Consists of all teachers in primary stage in North Greenline, and their number is almost (4567), a teacher, during the 2nd semester of the scholastic year 2020/2021.

Study sample:

A random sample were selected, included the sample on (450) teacher. Table (1) shows the distribution of the study sample according to the independent variables.

Table (1): The distribution of the study sample according to the levels of its variables

\begin{tabular}{|c|c|c|c|}
\hline variable & the level/Category & the number & Percentage $\%$ \\
\hline \multirow[t]{2}{*}{ Gender } & Male & 52 & $11.6 \%$ \\
\hline & female & 398 & $88.4 \%$ \\
\hline \multirow[t]{2}{*}{ qualification } & Bachelor & 90 & $20.0 \%$ \\
\hline & studies for me & 360 & $80.0 \%$ \\
\hline \multirow[t]{3}{*}{$\begin{array}{l}\text { Years } \\
\text { Experience }\end{array}$} & Less From five Years & 58 & $12.9 \%$ \\
\hline & From 5-10 Years & 327 & $72.7 \%$ \\
\hline & More From 10 Years & 65 & $14.4 \%$ \\
\hline \multirow[t]{2}{*}{ Job } & Class Teacher & 320 & $71.1 \%$ \\
\hline & $\begin{array}{ll}\text { Integration } & \text { Qualified } \\
\text { Teacher } & \end{array}$ & 130 & $28.9 \%$ \\
\hline \multirow[t]{7}{*}{ Limitations } & Autism & 125 & $27.8 \%$ \\
\hline & blindness & 76 & $16.9 \%$ \\
\hline & Deafness & 46 & $10.2 \%$ \\
\hline & $\begin{array}{ll}\text { Mentality } & \text { development } \\
\text { limitations } & \\
\end{array}$ & 48 & $10.7 \%$ \\
\hline & Physical limitation & 43 & $9.6 \%$ \\
\hline & $\begin{array}{l}\text { Psychological } \\
\text { Disturbances }\end{array}$ & 40 & $8.9 \%$ \\
\hline & $\begin{array}{l}\text { Simple diseases } \\
\text { syndrome }\end{array}$ & 72 & $16.0 \%$ \\
\hline
\end{tabular}

\section{Study tool:}

For the purposes of the application of the tool study was reference to the literature of educational studies and previous related to the concept of comprehensive integration, as it puts the responder signal in front of each paragraph of the paragraphs of the areas and so on the ladder of five levels are (large very, large, medium, low, low too) and corrected tool by giving weights Next $(1,2,3,4,5)$ to the degrees of the previous mentioned, as has been verified from the semantics of honesty and consistency of the instrument.

\section{Questionnaire validity:}

The questionnaire was applied to an exploratory sample consisting of (30) teachers from the study population, and they were excluded from the study sample. It was the expense of transactions correlation between the degree of each paragraph with a degree college for the area which belongs to the paragraph. The correlation coefficients between the degree of each field of the questionnaire with the total score of the questionnaire were calculated.

\section{Study tool:}

For the purposes of the application of the tool has been back to the literature of educational studies and previous related to the concept of integration. It puts responder signal in front 
of each paragraph of the paragraphs of the areas, as has been verified from the semantics of honesty and consistency of the instrument.

The application of the questionnaire on a sample exploratory sample of (30) teachers of the community study, were excluded from the sample study. correlation was estimated between the degree of each items with a degree for the domain. also, correlation between the degree of each domain of the questionnaire with the total degree for a questionnaire, and each item with the field with the overall tool, as showing that the links were larger than $(0.20)$ which is appropriate for the purposes of achieving the objectives of the study current.

\section{Study reliability:}

Two methods were used to verify the stability of the study tool, the first method is testing and retesting, and the second method is the calculation of the Cronbach coefficient for the items of the questionnaire. Where it was in the first application of the questionnaire on the sample reconnaissance (30 teachers) twice ahead of time duration of two weeks was calculating coefficient of correlation Pearson (coefficient of reliability) between the two applications. As has been the way the second calculation coefficient stability of the consistency of internal than through the coefficient of Cronbach 's alpha.

Table (2): coefficient of stability of repetition and consistency of internal Cronbach alpha tool integration as a whole and its fields

\begin{tabular}{|l|r|r|}
\hline Domains & Internal consistency & Test-rest \\
\hline $\begin{array}{l}\text { Teachers 'experiences and qualification in } \\
\text { dealing with students with special needs who } \\
\text { are integrated into the regular school. }\end{array}$ & 0.891 & 0.911 \\
\hline $\begin{array}{l}\text { The psychological and social aspects in } \\
\text { dealing with students with special needs and } \\
\text { their families. }\end{array}$ & 0.856 & 0.872 \\
\hline Supportive environment. & 0.911 & 0.901 \\
\hline Total tool & 0.923 & 0.931 \\
\hline
\end{tabular}

Showed results in the table (2) that the test and re test were (0.931). and Cronbach Alpha" were (0. 923). which is high, and therefore considered these values appropriate for the purposes of this study, and to achieve its purpose and reliable results.

\section{Study variables:}

The study includes the variable of gender, academic qualification, years of experience, and job title, in addition to the limitations of the integrated student.

Statistical analysis methods:

To answer the questions the study of questions the study was the use of means and standard deviations, as well as multivariate analysis.

\section{Results:}

This study aimed to reveal the degree of application of the comprehensive integration of students with special needs between reality and expectations from the point of view of teachers in elementary schools in the Northern District within the Green Line. To achieve this, their questions were answered according to their sequence, and the following is a presentation of that:

The results of the question first, which state What is the degree of implementation of the comprehensive integration of students with special needs between reality and expectations from the point of view of teachers in primary schools in the northern district inside the Green Line?

To answer for this question; The calculation means and standard deviation were computed, and shows a table (3) that: 
Table (3): Means and standard deviations of members of a sample study on the items of the degree of application Comprehensive integration with special needs students

\begin{tabular}{|l|l|l|l|l|l|}
\hline No. & Domains & Means & $\begin{array}{l}\text { Standard } \\
\text { deviation }\end{array}$ & Rank & Degree \\
\hline 2 & $\begin{array}{l}\text { Aspects Mental And social in a Dealing } \\
\text { with Students with Needs Own And their } \\
\text { families. }\end{array}$ & 3.60 & 462 & 2 & Medium \\
\hline 3 & The Supportive environment. & 3.52 & 640 & 3 & Medium \\
\hline 1 & $\begin{array}{l}\text { Teachers Experiences and rehabilitation in } \\
\text { a Dealing with Students with Needs. }\end{array}$ & 3.29 & .629 & 1 & Medium \\
\hline & Overall means & 3.47 & 439 & - & Medium \\
\hline
\end{tabular}

Table (3) that the degree of implementation of the comprehensive integration of students with special needs between reality and expectations from the point of view of teachers in primary schools in the northern district inside the green line came degree (medium), The researcher attributes the result to the fact that the areas of acceptance of the idea of comprehensive integration in all fields, especially in the field of supportive environment, and psychological and social aspects in dealing with students with special needs and their families, to a large degree, because the study samples believe in the integrated student that he is no different from other ordinary students. also, this may be due to the influence of some factors such as the lack of completion available for regular teachers in the subject of special education, but according to the specialization: Arabic, English, mathematics and other sciences. That special education is part of general education.

And also, it has been calculating means and standard deviations on each item as shown in the following table.

Table (4) Means and Standard deviations for the items of "teachers experiences and rehabilitation

\begin{tabular}{|l|l|l|l|l|l|}
\hline No. & Items & Means & $\begin{array}{l}\text { Standard } \\
\text { deviation }\end{array}$ & Rank & Degree \\
\hline 8 & $\begin{array}{l}\text { I understand Definitions Different For } \\
\text { limitations requester Built from With } \\
\text { Needs Own. }\end{array}$ & 3.66 & 1.012 & 1 & Medium \\
\hline 6 & $\begin{array}{l}\text { Develop My abilities to deal With } \\
\text { Students with Needs Own. }\end{array}$ & 3.63 & 1.020 & 2 & Medium \\
\hline 2 & $\begin{array}{l}\text { I have Experiences to deal With Students } \\
\text { with Needs as Integrators inside Class. }\end{array}$ & 3.62 & 1.168 & 3 & Medium \\
\hline 5 & $\begin{array}{l}\text { Possess Skills Necessary To deal With } \\
\text { Students with Needs with integration } \\
\text { inside Class. }\end{array}$ & 3.62 & 1.127 & 4 & Medium \\
\hline 12 & $\begin{array}{l}\text { use Methods of Teaching To support the } \\
\text { Educational Learning operation for } \\
\text { Students with Needs Own. }\end{array}$ & 3.58 & 1.046 & 5 & Medium \\
\hline 3 & $\begin{array}{l}\text { I have Qualifying To deal With Students } \\
\text { with Needs inside Class. }\end{array}$ & 3.52 & 1.238 & 6 & Medium \\
\hline 7 & $\begin{array}{l}\text { Self development About the students } \\
\text { With Needs. }\end{array}$ & 3.52 & 1.123 & 7 & Medium \\
\hline 9 & $\begin{array}{l}\text { I have looking at Laws Related in } \\
\text { Merging Students with Needs }\end{array}$ & 3.50 & 1.087 & 8 & Medium \\
\hline 13 & $\begin{array}{l}\text { I agree On Merging Students with Needs. } \\
\text { I feel That I experienced an }\end{array}$ & 3.44 & 1.172 & 9 & Medium \\
\hline 11 & $\begin{array}{l}\text { I fingled } \\
\text { Implementation Techniques To determine }\end{array}$ & 984 & 10 & Medium \\
\hline
\end{tabular}




\begin{tabular}{|l|l|l|l|l|l|}
\hline & $\begin{array}{l}\text { Needs regarding Pedagogical and Social } \\
\text { And psychological for students With } \\
\text { Needs. }\end{array}$ & & & & \\
\hline 4 & $\begin{array}{l}\text { I participated in a Complements For } \\
\text { teachers Related By students With } \\
\text { Needs. }\end{array}$ & 3.13 & 1.543 & 11 & Medium \\
\hline 10 & $\begin{array}{l}\text { I need help in a Building the Individual } \\
\text { plan for Students with Needs inside } \\
\text { Class }\end{array}$ & 2.91 & 1.266 & 12 & Low \\
\hline 1 & $\begin{array}{l}\text { Presence of Person with Needs in teacher } \\
\text { family }\end{array}$ & 1.17 & 377 & 13 & Low \\
\hline & $\begin{array}{l}\text { Teachers Experiences And rehabilitate } \\
\text { them in a Dealing with Students with } \\
\text { Needs in the school Ordinary. }\end{array}$ & 3.29 & .629 & & Medium \\
\hline
\end{tabular}

Notes from a table (4) that means of the items of the field were from low to medium, the researcher attributes this result to the teachers not receiving training or going through experiences related to dealing with people with special needs even though they have different qualifications, but they did not study special education courses, and it may be due to the ability and skill of the teacher to communicate information For all students of different abilities, this differs from one teacher to another teacher. Some of them develop themselves due to lack of knowledge, and some of them increase their knowledge. also, the researcher attributes this result to the fact that the teacher's belief in students with special needs is not based on subjective experiences and prejudices, but rather from their faith in their students and their right to comprehensive inclusion.

The second domain: the psychological and social aspects in dealing with students with special needs and their families.

Table (5): Means and Standard deviation for the domain

\begin{tabular}{|c|c|c|c|c|c|}
\hline No. & Items & Means & $\begin{array}{l}\text { Standard } \\
\text { deviation }\end{array}$ & Rank & Degree \\
\hline 19 & $\begin{array}{l}\text { Awareness the students about } \\
\text { bullying }\end{array}$ & 4.00 & 987 & 1 & High \\
\hline 7 & $\begin{array}{l}\text { Taking into Consideration Mental } \\
\text { Factors for Students with Needs. }\end{array}$ & 3.97 & 955 & 2 & High \\
\hline 10 & $\begin{array}{l}\text { Reinforce Social communication } \\
\text { between the students With Needs } \\
\text { And their peers. }\end{array}$ & 3.78 & 986 & 3 & High \\
\hline 16 & $\begin{array}{l}\text { Strengthening Students with Needs } \\
\text { trust and self indepdencey. }\end{array}$ & 3.77 & .963 & 4 & High \\
\hline 12 & $\begin{array}{l}\text { Respect and consider the nature of } \\
\text { parents' remarks towards students } \\
\text { with special needs. }\end{array}$ & 3.76 & 974 & 5 & High \\
\hline 9 & $\begin{array}{l}\text { We work in the school to ensure } \\
\text { human rights for students With } \\
\text { Needs. }\end{array}$ & 3.74 & 978 & 6 & High \\
\hline 5 & $\begin{array}{l}\text { Merging students with special } \\
\text { needs in the school can lead to } \\
\text { accept all students' differences in } \\
\text { the class }\end{array}$ & 3.72 & 992 & 7 & High \\
\hline 2 & $\begin{array}{l}\text { Students with special needs } \\
\text { consume the time of the average }\end{array}$ & 3.62 & .950 & 8 & Medium \\
\hline
\end{tabular}




\begin{tabular}{|c|c|c|c|c|c|}
\hline & $\begin{array}{l}\text { teacher during the teaching- } \\
\text { learning process. }\end{array}$ & & & & \\
\hline 8 & $\begin{array}{l}\text { I am taking measures in school to } \\
\text { change society's perception of } \\
\text { students with special needs. }\end{array}$ & 3.61 & 1.045 & 9 & Medium \\
\hline 18 & $\begin{array}{l}\text { I contributed in building social } \\
\text { relationships between students } \\
\text { with special needs and ordinary } \\
\text { students. }\end{array}$ & 3.57 & 953 & 10 & Medium \\
\hline 17 & $\begin{array}{l}\text { I contributed to building programs } \\
\text { for students with special needs to } \\
\text { face of the social isolation that } \\
\text { students with special needs suffers } \\
\text { from. }\end{array}$ & 3.54 & 974 & 11 & Medium \\
\hline 14 & $\begin{array}{l}\text { Regular students participate with } \\
\text { fellow students with special needs } \\
\text { in social activities outside of } \\
\text { school. }\end{array}$ & 3.50 & .997 & 12 & Medium \\
\hline 13 & $\begin{array}{l}\text { Regular students understand the } \\
\text { needs of their fellow students with } \\
\text { special needs. }\end{array}$ & 3.49 & 873 & 13 & Medium \\
\hline 3 & $\begin{array}{l}\text { Inclusion of students with special } \\
\text { needs affects a teacher's interest in } \\
\text { regular students. }\end{array}$ & 3.48 & 970 & 14 & Medium \\
\hline 11 & $\begin{array}{l}\text { I offer awareness to families of } \\
\text { ordinary students to accept } \\
\text { students with special needs }\end{array}$ & 3.43 & 1.084 & 15 th & Medium \\
\hline 15 & $\begin{array}{l}\text { Provide all possibilities to integrate } \\
\text { students with special needs into } \\
\text { the classroom. }\end{array}$ & 3.43 & 881 & 16 & Medium \\
\hline 1 & $\begin{array}{l}\text { I am personally ready to accept the } \\
\text { integration of students with special } \\
\text { needs from difficult disabilities, } \\
\text { diseases and rare syndromes. }\end{array}$ & 3.37 & 1.130 & 17 & Medium \\
\hline 6 & $\begin{array}{l}\text { The comprehensive inclusion } \\
\text { creates opportunities for scientific } \\
\text { competition, which improves the } \\
\text { academic aspect of students with } \\
\text { special needs. }\end{array}$ & 3.36 & .969 & 18 & Medium \\
\hline 4 & $\begin{array}{l}\text { The educational activities carried } \\
\text { out by the average teacher are } \\
\text { commensurate with the ordinary } \\
\text { students of the integrated students } \\
\text { with special needs }\end{array}$ & 3.17 & .947 & 19 & Medium \\
\hline & $\begin{array}{l}\text { the psychological and social } \\
\text { aspects in dealing with students } \\
\text { with special needs and their } \\
\text { families. }\end{array}$ & 3.60 & .462 & & High \\
\hline
\end{tabular}

It is noticed from Table (5) that the means were high for the domain "Aspects Mental And social in a Dealing with Students with Needs Own And their families", the researcher attributes the result to awareness and perception of the concept of comprehensive inclusion and its psychological, social and academic implications and the success of social interaction. also, the researcher attributes this result to the lack of experience of teachers towards integrated students due to the absence of the necessary qualification for them because special education is part of public education. 
The third domain: the supportive environment:

Table (6): Means and SD for the domain (environment supportive)

\begin{tabular}{|c|c|c|c|c|c|}
\hline No. & Items & Means & $\begin{array}{l}\text { Standard } \\
\text { deviation }\end{array}$ & Rank & Degree \\
\hline 1 & $\begin{array}{lrr}\begin{array}{l}\text { It } \quad \text { works } \\
\text { communication }\end{array} & \text { to } & \text { stimulate } \\
\text { communication } & \text { skills } & \text { and } \\
\text { students. } & & \\
\end{array}$ & 3.73 & .966 & 1 & High \\
\hline 3 & $\begin{array}{l}\text { The administration follows up } \\
\text { procedures for dealing with } \\
\text { students with special needs. }\end{array}$ & 3.72 & .970 & 3 & High \\
\hline 2 & $\begin{array}{l}\text { Empowering students with the } \\
\text { ability to build work teams. }\end{array}$ & 3.58 & .819 & 2 & High \\
\hline 5 & $\begin{array}{l}\text { The appropriate educational } \\
\text { facilities and means are available } \\
\text { for students with special needs. }\end{array}$ & 3.47 & .967 & 5 & Medium \\
\hline 4 & $\begin{array}{l}\text { The available curricula contribute } \\
\text { to responding to the integration } \\
\text { needs of students with special } \\
\text { needs. }\end{array}$ & 3.42 & 1.063 & 4 & Medium \\
\hline 6 & $\begin{array}{l}\text { The classroom environment is } \\
\text { suitable for integrating students } \\
\text { with special needs. }\end{array}$ & 3.36 & 1.076 & 6 & Medium \\
\hline \multirow[t]{2}{*}{7} & $\begin{array}{l}\text { The school building takes into } \\
\text { consideration the needs of } \\
\text { students with special needs. }\end{array}$ & 3.36 & 1.088 & 7 & Medium \\
\hline & the supportive environment. & 3.52 & .640 & & Medium \\
\hline
\end{tabular}

Table (6) indicate the means were medium for the supportive environment domain the researcher attributes this result to the fact that teachers know and believe that the integrated student is no different from other ordinary students. also, the researcher attributes that the curricula do not activate and enhance the comprehensive integration process, as well as the educational means and methods must take into account the needs of students with special needs and the suitability of the curricula for them.

Results the 2nd question that state: "Are there any statistically significant differences at the level of significance $(\alpha=0.05)$ In the areas of the reality of the comprehensive integration of students with special needs due to the differences within the independent variables for each of (gender, academic qualification, years of experience, job title, integration teacher, regular teacher, the presence of a person with special needs in the teacher family, student limitations)

To answer this question; the researcher computed the means and standard deviations as shown in the following table (7).

Table (7): Average's calculations and deviations of the standard estimates of members of a sample study on the areas of study according to the variables of the study

\begin{tabular}{|c|l|l|l|l|l|}
\hline Variables & \multicolumn{2}{|l|}{$\begin{array}{l}\text { Teacher } \\
\text { experiences } \\
\text { and } \\
\text { qualification. }\end{array}$} & $\begin{array}{l}\text { Psychological } \\
\text { and social } \\
\text { aspects }\end{array}$ & $\begin{array}{l}\text { Supportive } \\
\text { environment. }\end{array}$ & $\begin{array}{l}\text { All } \\
\text { items }\end{array}$ \\
\hline \multicolumn{2}{|l|}{} & 3.66 & 3.61 & gender \\
\hline Male & Means & 2.92 & & \\
\hline
\end{tabular}




\begin{tabular}{|c|c|c|c|c|c|}
\hline Variables & & $\begin{array}{l}\text { Teacher } \\
\text { experiences } \\
\text { and } \\
\text { qualification. }\end{array}$ & $\begin{array}{l}\text { Psychological } \\
\text { and social } \\
\text { aspects }\end{array}$ & $\begin{array}{l}\text { Supportive } \\
\text { environment. }\end{array}$ & $\begin{array}{l}\text { All } \\
\text { items }\end{array}$ \\
\hline & $\mathrm{N}$ & 52 & 52 & 52 & 52 \\
\hline & SD & .661 & .361 & .378 & .238 \\
\hline \multirow{3}{*}{ Female } & Means & 3.33 & 3.59 & 3.51 & 3.48 \\
\hline & $\mathrm{N}$ & 398 & 398 & 398 & 398 \\
\hline & $\mathrm{SD}$ & .609 & .473 & .666 & .458 \\
\hline \multicolumn{6}{|c|}{ Qualification } \\
\hline \multirow[t]{3}{*}{ Bachelor } & Means & 3.23 & 3.55 & 3.44 & 3.41 \\
\hline & $\mathrm{N}$ & 90 & 90 & 90 & 90 \\
\hline & $\mathrm{SD}$ & .546 & .459 & .647 & .430 \\
\hline \multirow[t]{3}{*}{ Higher studies } & Means & 3.30 & 3.61 & 3.54 & 3.48 \\
\hline & $\mathrm{N}$ & 360 & 360 & 360 & 360 \\
\hline & $\mathrm{SD}$ & .648 & .463 & .638 & .440 \\
\hline \multicolumn{6}{|c|}{ Experienc } \\
\hline \multirow[t]{3}{*}{$\begin{array}{cc}\text { Less } & \text { than } 5 \\
& \text { years } \\
\end{array}$} & Means & 3.27 & 3.56 & 3.76 & 3.53 \\
\hline & $\mathrm{N}$ & 58 & 58 & 58 & 58 \\
\hline & $\mathrm{SD}$ & .507 & .534 & .742 & .492 \\
\hline \multirow[t]{3}{*}{$5-10$ years } & Means & 3.27 & 3.59 & 3.46 & 3.44 \\
\hline & $\mathrm{N}$ & 327 & 327 & 327 & 327 \\
\hline & $\mathrm{SD}$ & .655 & .437 & .606 & .422 \\
\hline \multirow[t]{3}{*}{$\begin{array}{c}\text { More than } 10 \\
\text { years }\end{array}$} & Means & 3.36 & 3.65 & 3.64 & 3.55 \\
\hline & $\mathrm{N}$ & 65 & 65 & 65 & 65 \\
\hline & $\mathrm{SD}$ & .592 & .518 & .654 & .462 \\
\hline \multicolumn{6}{|c|}{ Limitations of Integrated Students in the classLimited Mentality Evolutionary } \\
\hline \multicolumn{6}{|l|}{ Autism } \\
\hline \multirow[t]{3}{*}{ Means } & 3.10 & 3.54 & 3.46 & 3.37 & \\
\hline & $\mathrm{N}$ & 125 & 125 & 125 & 125 \\
\hline & $\mathrm{SD}$ & .528 & .394 & .681 & .383 \\
\hline \multirow[t]{3}{*}{ blindness } & Means & 3.15 & 3.53 & 3.41 & 3.36 \\
\hline & $\mathrm{N}$ & 76 & 76 & 76 & 76 \\
\hline & $\mathrm{SD}$ & .567 & .401 & .629 & .417 \\
\hline \multirow[t]{3}{*}{ Deafness } & Means & 3.17 & 3.57 & 3.56 & 3.43 \\
\hline & $\mathrm{N}$ & 46 & 46 & 46 & 46 \\
\hline & $\mathrm{SD}$ & .487 & .472 & .609 & .373 \\
\hline \multirow[t]{3}{*}{$\begin{array}{l}\text { Mentality } \\
\text { development } \\
\text { limitations }\end{array}$} & Means & 3.25 & 3.39 & 3.43 & 3.35 \\
\hline & $\mathrm{N}$ & 48 & 48 & 48 & 48 \\
\hline & SD & .456 & .342 & .695 & .353 \\
\hline \multirow[t]{3}{*}{$\begin{array}{l}\text { Limited } \\
\text { Physical }\end{array}$} & Means & 3.04 & 3.51 & 3.45 & 3.33 \\
\hline & $\mathrm{N}$ & 43 & 43 & 43 & 43 \\
\hline & $\mathrm{SD}$ & .624 & .414 & .560 & .365 \\
\hline $\begin{array}{l}\text { Disturbances } \\
\text { Psychological }\end{array}$ & Means & 3.24 & 3.50 & 3.59 & 3.44 \\
\hline
\end{tabular}




\begin{tabular}{|c|c|c|c|c|c|}
\hline Variables & & $\begin{array}{l}\text { Teacher } \\
\text { experiences } \\
\text { and } \\
\text { qualification. }\end{array}$ & $\begin{array}{l}\text { Psychological } \\
\text { and social } \\
\text { aspects }\end{array}$ & $\begin{array}{l}\text { Supportive } \\
\text { environment. }\end{array}$ & $\begin{array}{l}\text { All } \\
\text { items }\end{array}$ \\
\hline & $\mathrm{N}$ & 40 & 40 & 40 & 40 \\
\hline & SD & .509 & .303 & .491 & .304 \\
\hline \multirow[t]{3}{*}{$\begin{array}{l}\text { Simple } \\
\text { diseases and } \\
\text { syndrome }\end{array}$} & Means & 4.04 & 4.02 & 3.78 & 3.95 \\
\hline & $\mathrm{N}$ & 72 & 72 & 72 & 72 \\
\hline & SD & .560 & .551 & .623 & .439 \\
\hline \multicolumn{6}{|r|}{ Job title } \\
\hline \multirow[t]{3}{*}{ Class teacher } & Means & 3.11 & 3.57 & 3.53 & 3.41 \\
\hline & $\mathrm{N}$ & 320 & 320 & 320 & 320 \\
\hline & SD & .584 & .466 & .688 & .447 \\
\hline \multirow[t]{3}{*}{$\begin{array}{r}\text { Qualified } \\
\text { integration } \\
\text { teacher } \\
\end{array}$} & Means & 3.71 & 3.65 & 3.51 & 3.62 \\
\hline & $\mathrm{N}$ & 130 & 130 & 130 & 130 \\
\hline & $\mathrm{SD}$ & .529 & .450 & .504 & .376 \\
\hline \multirow[t]{3}{*}{ Total } & Means & 3.29 & 3.60 & 3.52 & 3.47 \\
\hline & $\mathrm{N}$ & 450 & 450 & 450 & 450 \\
\hline & SD & .629 & .462 & .640 & .439 \\
\hline
\end{tabular}

It is noted from Table (7) that there are apparent differences between the arithmetic averages of the estimates of the study sample individuals about the areas of comprehensive integration, according to the study variables, and to determine the statistical significance of these apparent differences, the multiple variance analysis has been applied, and Table (9) shows that.

Table (8) multivariate analysis of the arithmetic means of estimates of the study sample individuals on comprehensive inclusion

\begin{tabular}{|l|l|l|l|l|l|l|}
\hline variable & Domains & $\begin{array}{l}\text { sum } \\
\text { Squares }\end{array}$ & $\begin{array}{l}\text { Degrees } \\
\text { of } \\
\text { freedom }\end{array}$ & $\begin{array}{l}\text { Average } \\
\text { of } \\
\text { squares }\end{array}$ & $\begin{array}{l}\text { Ph } \\
\text { value }\end{array}$ & $\begin{array}{l}\text { Statistical } \\
\text { significance }\end{array}$ \\
\hline & $\begin{array}{l}\text { teachers' } \\
\text { experiences and } \\
\text { qualification in } \\
\text { dealing with } \\
\text { students with } \\
\text { special needs who } \\
\text { are integrated into } \\
\text { the regular school. }\end{array}$ & 324 & 1 & 324 & 1.308 & 253 \\
\hline & $\begin{array}{l}\text { the psychological } \\
\text { and social aspects } \\
\text { in dealing with } \\
\text { students with } \\
\text { special needs and } \\
\text { their families. }\end{array}$ & 025 & 1 & 025 & 138 & .711 \\
\hline & $\begin{array}{l}\text { the supportive } \\
\text { environment. }\end{array}$ & .007 & 1 & .007 & 017 & .897 \\
\hline & \begin{tabular}{l} 
All domains \\
\hline
\end{tabular} & 012 & 1 & 012 & 078 & .780 \\
\hline
\end{tabular}




\begin{tabular}{|c|c|c|c|c|c|c|}
\hline variable & Domains & $\begin{array}{l}\text { sum } \\
\text { Squares }\end{array}$ & $\begin{array}{l}\text { Degrees } \\
\text { of } \\
\text { freedom }\end{array}$ & $\begin{array}{l}\text { Average } \\
\text { of } \\
\text { squares }\end{array}$ & $\begin{array}{l}\mathrm{Ph} \\
\text { value }\end{array}$ & $\begin{array}{l}\text { Statistical } \\
\text { significance }\end{array}$ \\
\hline \multirow[t]{4}{*}{ Qualification } & $\begin{array}{lr}\text { teachers' } & \\
\text { experiences } & \text { and } \\
\text { qualification } & \text { in } \\
\text { dealing } & \text { with } \\
\text { students } & \text { with } \\
\text { special needs } & \text { who } \\
\text { are integrated into } \\
\text { the regular school. }\end{array}$ & 712 & 1 & .712 & 2.872 & 091 \\
\hline & $\begin{array}{l}\text { the psychological } \\
\text { and social aspects } \\
\text { in dealing with } \\
\text { students with } \\
\text { special needs and } \\
\text { their families. }\end{array}$ & 201 & 1 & 201 & 1.117 & 291 \\
\hline & $\begin{array}{l}\text { the supportive } \\
\text { environment. }\end{array}$ & 308 & 1 & 308 & .759 & .384 \\
\hline & All domains & 379 & 1 & 379 & 2.455 & 118 \\
\hline \multirow[t]{4}{*}{$\begin{array}{l}\text { Years of } \\
\text { Experience }\end{array}$} & \begin{tabular}{lr} 
teachers' & \\
experiences & and \\
qualification & in \\
dealing & with \\
students & with \\
special needs & who \\
are integrated into \\
\multicolumn{2}{l}{ the regular school. } \\
\end{tabular} & 597 & 2 & 298 & 1.203 & 302 \\
\hline & $\begin{array}{l}\text { the psychological } \\
\text { and social aspects } \\
\text { in dealing with } \\
\text { students with } \\
\text { special needs and } \\
\text { their families. }\end{array}$ & .231 & 2 & 115 & 641 & .527 \\
\hline & $\begin{array}{l}\text { the supportive } \\
\text { environment. }\end{array}$ & .653 & 2 & 326 & 803 & .449 \\
\hline & All domains & 252 & 2 & 126 & 814 & .444 \\
\hline \multirow[t]{4}{*}{ Job title } & $\begin{array}{lr}\text { teachers' } & \\
\text { experiences } & \text { and } \\
\text { qualification } & \text { in } \\
\text { dealing } & \text { with } \\
\text { students } & \text { with } \\
\text { special needs } & \text { who } \\
\text { are integrated into } \\
\text { the regular school. }\end{array}$ & 3.429 & 1 & 3.429 & 13.828 & .000 \\
\hline & $\begin{array}{l}\text { the psychological } \\
\text { and social aspects } \\
\text { in dealing with } \\
\text { students with } \\
\text { special needs and } \\
\text { their families. }\end{array}$ & 029 & 1 & 029 & .163 & 686 \\
\hline & $\begin{array}{l}\text { the supportive } \\
\text { environment. }\end{array}$ & .403 & 1 & .403 & 992 & 320 \\
\hline & All domains & 121 & 1 & 121 & 786 & 376 \\
\hline $\begin{array}{l}\text { Limitations of } \\
\text { the built-in } \\
\text { student }\end{array}$ & $\begin{array}{lr}\text { teachers' } & \\
\text { experiences } & \text { and } \\
\text { qualification } & \text { in } \\
\end{array}$ & 3.412 & 6 & 569 & 2.293 & 035 \\
\hline
\end{tabular}




\begin{tabular}{|c|c|c|c|c|c|c|}
\hline variable & Domains & $\begin{array}{l}\text { sum } \\
\text { Squares }\end{array}$ & $\begin{array}{l}\text { Degrees } \\
\text { of } \\
\text { freedom }\end{array}$ & $\begin{array}{l}\text { Average } \\
\text { of } \\
\text { squares }\end{array}$ & $\begin{array}{l}\mathrm{Ph} \\
\text { value }\end{array}$ & $\begin{array}{l}\text { Statistical } \\
\text { significance }\end{array}$ \\
\hline & $\begin{array}{ll}\text { dealing } & \text { with } \\
\text { students } & \text { with } \\
\text { special needs } & \text { who } \\
\text { are integrated into } \\
\text { the regular school. }\end{array}$ & & & & & \\
\hline & $\begin{array}{l}\text { the psychological } \\
\text { and social aspects } \\
\text { in dealing with } \\
\text { students with } \\
\text { special needs and } \\
\text { their families. }\end{array}$ & 5.018 & 6 & .836 & 4.649 & .000 \\
\hline & $\begin{array}{l}\text { the supportive } \\
\text { environment. }\end{array}$ & 3.291 & 6 & .549 & 1.350 & .234 \\
\hline & All domains & 3.520 & 6 & .587 & 3.797 & .001 \\
\hline \multirow[t]{4}{*}{ error } & $\begin{array}{lr}\text { teachers' } & \\
\text { experiences } & \text { and } \\
\text { qualification } & \text { in } \\
\text { dealing } & \text { with } \\
\text { students } & \text { with } \\
\text { special needs } & \text { who } \\
\text { are integrated into } \\
\text { the regular school. }\end{array}$ & 88,529 & 357 & 248 & & \\
\hline & $\begin{array}{l}\text { the psychological } \\
\text { and social aspects } \\
\text { in dealing with } \\
\text { students } \\
\text { special needs and } \\
\text { their families. }\end{array}$ & 64.217 & 357 & 180 & & \\
\hline & $\begin{array}{l}\text { the supportive } \\
\text { environment. }\end{array}$ & 145.045 & 357 & .406 & & \\
\hline & All domains & 55.158 & 357 & 155 & & \\
\hline \multirow[t]{3}{*}{ Total } & $\begin{array}{lr}\text { teachers' } & \\
\text { experiences } & \text { and } \\
\text { qualification } & \text { in } \\
\text { dealing } & \text { with } \\
\text { students } & \text { with } \\
\text { special needs } & \text { who } \\
\text { are integrated into } \\
\text { the regular school. }\end{array}$ & 5038.083 & 450 & & & \\
\hline & $\begin{array}{l}\text { the psychological } \\
\text { and social aspects } \\
\text { in dealing with } \\
\text { students } \\
\text { special needs and } \\
\text { their families. }\end{array}$ & 5916.493 & 450 & & & \\
\hline & $\begin{array}{l}\text { the supportive } \\
\text { environment. }\end{array}$ & 5761.673 & 450 & & & \\
\hline
\end{tabular}




\section{The previous table showed the following:}

1. The absence of statistically significance differences on the dons aims of study due to gender, and this can be attributed this result to the merger laws apply to all schools.

2. The absence of statistically significant differences in the first field and the total tool according to the scientific qualification variable, and this result can be attributed to the fact that the scientific qualification variable was not an influencing factor.

3. The absence of statistically significant differences in all fields according to the variable of years of experience. The researcher attributes the result to the fact that teachers received the same education, whether in colleges or universities, and received the same training, as well as all of them living with the same conditions, customs and traditions, and no difference in social and cultural factors.

4. The existence of statistically significant differences in all fields according to the job title variable, and the differences were in favor of the integration teacher. The researcher attributes the result to the fact that the integration teacher received training or courses in the field of education, their knowledge of the laws on comprehensive integration, and their silver knowledge of dealing and caring for the integrated students.

5. The existence of statistically significant differences in the first field and the second field and the overall tool according to the variable limitations of the combined student, where the differences were in favor of simple diseases and syndromes as shown in Table (10) the researcher attributed the result to the lack of awareness or weakness of control of the importance of implementing regulations and laws related to the family Special needs as well as increasing parents' awareness of the importance of comprehensive integration, which constitutes a positive impact on the student and the possibility of his removal and integration into society.

Table (9): Schefaee analysis for

\begin{tabular}{|l|l|l|l|}
\hline \begin{tabular}{l} 
(I) Limitations $\begin{array}{r}\text { Integrated Students in the } \\
\text { class }\end{array}$ \\
\hline $\begin{array}{l}\text { Simple diseases and } \\
\text { syndrome }\end{array}$
\end{tabular} & $\begin{array}{l}(\mathrm{J}) \text { Limitations of } \\
\text { class }\end{array}$ & $\begin{array}{l}\text { The difference } \\
\text { between the two } \\
\text { averages }\end{array}$ & Sig. \\
\hline & $.58\left(^{*}\right)$ & .000 \\
\hline & blindness & $.59\left(^{*}\right)$ & .000 \\
\hline & Deafness development & $.52\left(^{*}\right)$ & .000 \\
\hline & $\begin{array}{l}\text { Mentality } \\
\text { limitations }\end{array}$ & .000 \\
\hline & Limited Physical & $.62\left(^{*}\right)$ & .000 \\
\hline & Disturbances Psychological & $.51\left(^{*}\right)$ & .000 \\
\hline
\end{tabular}

\section{Recommendations:}

In light of the results of the study, the researcher recommends the following:

1. Teaching special education courses in universities and colleges is part of the qualification, and the course is compulsory and not optional

2. Conducting completion courses for professional development on the subject of special education and opening the way for all groups of teachers to join the completions.

3. Exchange of experiences between teachers of inclusion and regular education teachers

4. Parents' participation in the importance of the comprehensive integration process through seminars and workshops.

5. Work on how to build an individual plan for its importance in the development of students with special needs

\section{References:}

Abraham, Moses. (2005). Disability in the Arab World, Beirut: Dar Al-Nahda.

Ali, Mervat. (2013). Contemporary trends in the education of the deaf and hard of hearing. Amman: House of Thought.

Al-Muzairiy, Yazid. Hanafi, Ali. (2019). Teachers' expectations towards implementing comprehensive education for deaf and hard of hearing students in public 
education schools in Riyadh, Arab Journal of Disability and Gifted Sciences, Volume Three, Issue (9), pp. 399-430.

Al-Najjar, Abdullah Hussein. And Jundi, Murad Rushdie. (2014). Attitudes of primary school teachers in South Hebron education schools towards integrating the disabled in their schools from their point of view, Journal of Al-Quds Open University for Research and Studies, Palestine.

Al-Otaibi, Bandar. (2002). The comprehensive integration of students with severe disabilities, its nature, methods, and effectiveness, Special Education Department. College of Education, King Saud University, Riyadh, Kingdom of Saudi Arabia, a study presented to the Eighth National Conference of the Federation of Special Groups and Handicapped Bodies in the Arab Republic of Egypt.

Al-Sharaa, Faisal. Melhem, Aida. (2014). Attitudes of lower primary school teachers in Mafraq governorate towards students with learning disabilities who are integrated into regular schools. Journal of Studies in Higher Education. Issue (6) p. 270, Assiut University.

Al-Shekhaibi, Ali. (2009). Contemporary Sociology of Education: Development of Methodology and Equal Educational Opportunities, Dar Al Fikr Al Arabi, Cairo.

Al-Zuhairi, Ibrahim Abbas. (2003). Raising the handicapped and talented people and organizing their education within a philosophical framework and international experiences, Arab Thought House, Cairo.

Ayran, Roti. Habbar, Israel. Efrati, Unit. Rick, Gabe Adamon. (2017). United Nations Convention on the Rights of Persons with Disabilities, Handbook for the Public, Commission for Equal Rights of Persons with Disabilities, Ministry of Justice, Third Edition, Print: Ubibret 2005 Ltd. file: / / C: / Users / user / Downloads / AmanaGuideArabic\% 20 (1) .pdf

Gemma, Emmanuel Kofi. (2009). The integration of children with special educational needs in general education schools in Ghana: the impact of the characteristics of teachers and children. International Journal of inclusive education, Vol. 13 Issue 8, Pages 787-804.

Hopps, N. W. (2002). A comparison of special and regular education teachers' knowledge of laws and policies on inclusion (Order No. 3219938). Available from ProQuest Dissertations \& Theses Global. https://www.elibrary.ru/item.asp?id=9412364

Israel, Guide, https://www.aisrael.org/?CategoryID=3171, taken on February 23, 2021, at 12:30.

Khatib, Jamal. (2008). Contemporary Special Education Issues and Trends, Wael Publishing and Distribution House, Amman.

Ministry of Education, State of Israel, Parents' Portal for Children with Special Needs.

Nawasrah, Faisal. Forgotten, good. (2018). Teachers 'attitudes towards integrating people with special needs with ordinary students in the basic stage in Ajloun Governorate / Jordan schools. An-Najah University Journal for Research and Human Sciences, Volume 32 (12).

Pantila, b. (2008). Attitudes and the concept of basic education teachers in Greece and Cyprus towards the education of students with special educational needs in mainstream schools/ public. International Journal of inclusive education, Volume 12-Issue 2, Pages 201 -219, 3 charts. European Journal of Special Needs Education, 25(1), 59-75.

Potros, H. (2010). Adaptation of curricula for students with special needs, Dar Al Masirah, Amman.

Saeed A. (2003). Fundamentals of Training for People with Special Needs, Amman: Dar Al Shorouk for Publishing and Distribution.

Sweiti, Abdel Nasser. (2016). Attitudes and opinions of teachers and administrators in public education towards the inclusion of extraordinary children in regular primary schools in the Hebron area. Journal of the College of Basic Education 
for Educational and Human Sciences, Issue (25), pp. 132-144, University of Babylon.

UNESCO. (1994). Final Report: World conference on special needs education: Access and quality. Paris: UNESCO (Salamanca).

UNESCO. (2008). Convivencia democrática, inclusión y cultura de paz. Santiago: OREALC/UNESCO. Retrieved from: http: / / unesdoc.unesco.org/images/0016/001621/162184s.pdf

Varnado, K. (2002). Teacher and administrators' attitude regarding inclusion with in a selected school district. Dissertation Abstracts International, 63 